\title{
PREVALENCE OF AUTOIMMUNE THYROID DISEASE AND THYROID DYSFUNCTION IN TYPE 1 DIABETES MELLITUS PATIENTS- A TERTIARY CARE CENTRE BASED STUDY IN ASSAM MEDICAL COLLEGE AND HOSPITAL, DIBRUGARH, ASSAM
}

\author{
Pranjal Kumar Dutta', Anupam Dutta², Apurba Dutta³, Sanjeeb Kakati', Lahari Saikia ${ }^{5}$ \\ ${ }^{1}$ Assistant Professor, Department of Medicine, Assam Medical College and Hospital, Dibrugarh, Assam. \\ ${ }^{2}$ Assistant Professor, Department of Medicine, Assam Medical College and Hospital, Dibrugarh, Assam. \\ ${ }^{3}$ Registrar, Department of Medicine, Assam Medical College and Hospital, Dibrugarh, Assam. \\ ${ }^{4}$ Professor, Department of Medicine, Assam Medical College and Hospital, Dibrugarh, Assam. \\ 5Professor, Department of Microbiology, Assam Medical College and Hospital, Dibrugarh, Assam.
}

\section{ABSTRACT}

\section{BACKGROUND}

Patients with an autoimmune condition are known to be at higher risk of developing other autoimmune disorders. Type 1 diabetes mellitus may be associated with additional autoimmune disorders including autoimmune thyroid disease. Studies investigating the autoimmune thyroid disease in T1DM are few.

The aim of this study was to investigate the prevalence of anti-TPO antibody and their clinical significance for development of thyroid disorder in patients with T1DM, attending the outpatient and in-patient department of Assam Medical College \& Hospital, Dibrugarh.

\section{MATERIALS AND METHODS}

This study was a hospital-based observational study, analysing all the previous and newly diagnosed T1DM patients done from a period of $1^{\text {st }}$ July 2016 to $30^{\text {th }}$ June 2017. 92 T1DM patients were evaluated with anti-TPO antibody by ELISA method and serum TSH measurement was done.

\section{RESULTS}

The anti-TPO antibody positivity was found in 9 out of the 92 patients with overall prevalence of 9.78\%. Among the anti-TPOpositive subjects, female to male ratio is $2: 1$. All the anti-TPO antibody positive patients had abnormal TSH levels and $44.45 \%$ had clinically significant hypothyroidism, $22.22 \%$ had subclinical hypothyroidism while hyperthyroidism was present in $33.33 \%$.

\section{CONCLUSION}

Our study reveals that there is a moderate prevalence of autoimmune thyroiditis in T1DM patients in this region and they should be followed up with regular screening of anti-TPO and TSH to make an early diagnosis of thyroid dysfunction.

\section{KEYWORDS}

T1DM= Type 1 Diabetes Mellitus; AITD= Autoimmune Thyroiditis; AIG= Autoimmune Gastritis; PA= Pernicious Anaemia; Anti-TPO = Anti-thyroperoxidase Antibody; TSH= Thyroid Stimulating Hormone; ELISA= Enzyme Linked Immune Sorbent Assay; TAA= Thyroid Autoantibody; HLA= Human Leucocyte Antigen; CTLA-4=Cytotoxic T Lymphocyte Antigen 4; CD = Coeliac Disease.

HOW TO CITE THIS ARTICLE: Dutta PK, Dutta A, Dutta A, et al. Prevalence of autoimmune thyroid disease and thyroid dysfunction in type 1 diabetes mellitus patients- A tertiary care centre based study in Assam medical college and hospital, Dibrugarh, Assam. J. Evolution Med. Dent. Sci. 2017;6(86):5955-5959, DOI: 10.14260/jemds/2017/1296

BACKGROUND
T1DM results from complex interaction of genetic, environmental and immunologic factors that ultimately lead to destruction of pancreatic beta cells and insulin deficiency.

Two HLA class II haplotype, DR4-DQ8 and DR3-DQ2 are present in about $90 \%$ of children with T1DM. Environmental triggers include viruses (Coxsackie, rubella, enterovirus), bovine milk proteins and nitrosourea.(1)

Type 1 DM may manifest at any age but most typically appears in childhood, especially around puberty. Worldwide,

'Financial or Other Competing Interest': None.

Submission 14-09-2017, Peer Review 13-10-2017,

Acceptance 19-10-2017, Published 26-10-2017.

Corresponding Author:

Dr. Pranjal Kumar Dutta,

Department of Medicine,

Assam Medical College and Hospital,

Dibrugarh, Assam.

E-mail: drpranjaldutta@rediffmail.com

DOI: $10.14260 /$ jemds/2017/1296 the incidence of T1DM varies 50 to 100 fold, with the highest rates occurring in individuals of northern European descent. (2)

In childhood both sexes are equally affected, but male predominance is seen in early adult life. Out of the estimated 422 million diabetic population in 2016, globally 5\% to $10 \%$ accounts for type 1 diabetes. Every year approximately 86,000 children under the age of 15 years, newly develop T1DM.(3) (4)

It is of two types. Type $1 \mathrm{~A}$ which is immune-mediated, accounts for over $95 \%$ of T1DM and is due to cellularmediated autoimmune destruction of the pancreatic $\beta$-cells in genetically predisposed individuals. Though common in childhood and adolescence, it can occur at any age, even in the $8^{\text {th }}$ and $9^{\text {th }}$ decades of life.

Idiopathic Type 1B occurs in minority of patients $(<5 \%)$ from African or Asian ancestry of unknown aetiology. This form of diabetes is strongly inherited and is not HLA associated. (5)

T1DM is most often associated with other autoimmune diseases like AITD, CD, AIG, PA and vitiligo. Out of these, 
autoimmune thyroid diseases are the most common form of autoimmune disorders ranging from $3 \%$ to $50 \%$ which is most often related to age, gender or ethnicity. (6) It is due to identical pathogenesis of the two disorders and shared genetic basis leading to frequent clustering within families and individuals. HLA- class II, cytotoxic T lymphocyte antigen 4 (CTLA-4) and protein tyrosine phosphatase non-receptor type 22 (PTPN22) have been suggested as potential genetic susceptibility loci.

Thyroid dysfunction has been reported in approximately $8 \%$ of patients.[6] Hashimoto's thyroiditis (Chronic autoimmune thyroiditis) and Graves' disease (thyromegaly and hyperthyroidism) are the major autoimmune thyroid diseases that occur with increased frequency in patients with T1DM. (7)

Autoimmune thyroid diseases, are most frequently associated with either primary or secondary autoantibodies. Primary antibodies are directly pathogenic and often directed against cell membrane receptors. They cause thyroid cell damage by complement activation and antibody dependent cell cytotoxicity.

Thyroperoxidase a $105 \mathrm{kDa}$ glycoprotein which catalyses iodine oxidation and thyroglobulin tyrosyl iodination reactions in the thyroid gland and is essential for active thyroid hormone T4 and T3 synthesis. When inhibited by anti-TPO Abs, the active T4, T3 synthesis decreases, resulting in low T4, T3 level and there is a compensatory increase in TSH level, which with increased anti-TPO titre and duration leads to deterioration of thyroid function from subclinical dysfunction to fully manifest clinical hypothyroidism. Secondary antibodies which include anti-thyroid peroxidase antibodies (anti-TPO antibodies), thyrotropin receptor antibodies (TRAbs) and thyroglobulin antibodies do not have role in pathogenesis but have useful diagnostic implication in autoimmune thyroid disease. Anti-TPO antibodies are specific for the autoantigen TPO, a $105 \mathrm{kDa}$ glycoprotein which catalyses iodine oxidation and thyroglobulin tyrosyl iodination reactions in the thyroid gland.

Anti-TPO antibodies are the most common anti-thyroid autoantibodies, present in approximately $90 \%$ of Hashimoto's thyroiditis, $75 \%$ of Graves' disease and 10 $20 \%$ of nodular goitre or thyroid carcinoma.

On the other hand, $10-15 \%$ of normal individuals can have high level anti-TPO antibody titres. Active phase chronic autoimmune thyroiditis is characterised by high serum antibody level. Lymphocytes infiltrating the thyroid gland are the major source of antibody with minor contribution from lymph node and bone marrow. (8)

Association of autoimmune thyroid disease may undermine diabetes control. For example, hyperthyroidism may worsen glycaemic control and increase insulin requirements.

On the other hand, hypothyroidism markedly alters carbohydrate metabolism. Exogenous insulin requirement may be lower as insulin degradation is less. Moreover, hypothyroidism often produces dyslipidaemias, including elevated triglyceride and LDL cholesterol concentrations. Thyroxin reverses these lipid abnormalities. But diagnosing thyroid dysfunction can be difficult. For example, poor glycaemic control produces symptoms similar to hyperthyroidism, such as weight loss despite increased appetite as well as fatigue. Clinicians need to be careful not to confuse severe diabetic nephropathy and hypothyroidism, as both produce oedema, fatigue, pallor and weight gain. Finally, poorly controlled diabetes may alter thyroid function. (9)

Against this background, the serum TSH immunoassay offers the most reliable and sensitive screening test for thyroid dysfunction. However, screening for anti-thyroid peroxidase (TPO) antibodies in people with type 1 diabetes may predict autoimmune thyroid disorders.

Management is generally similar to that in the nondiabetic population. However, L-thyroxin therapy may exacerbate angina by increasing myocardial contractility and heart rate. Clinicians should consider treating subclinical hypothyroidism if patients either have elevated serum LDL cholesterol exacerbated by hypothyroidism or detectable serum anti-TPO antibodies.

Thyroid dysfunction is common among diabetic patients and can produce metabolic disturbances. Therefore, regular screening of diabetic patients for thyroid dysfunction allows early treatment. T1DM patients expressing anti-TPO antibodies should be screened annually. In anti-TPO negative patients, a TSH assay every two to three years suffices.

Studies regarding the AITD in T1DM in India are limited. So considering all the above facts, this study was designed with the following objectives: To evaluate the association of AITD and its clinical profile among the type 1 diabetic patients.

\section{MATERIALS AND METHODS}

The present study was carried out on T1DM patients who attended the Out-Patient Department and / or were admitted in the various units of Department of Medicine, Assam Medical College and Hospital, Dibrugarh.

\section{Study Design}

This study was a hospital-based observational study done from the period of $1^{\text {st }}$ of July 2016 to $30^{\text {th }}$ June 2017, after getting ethical clearance from the institutional ethical committee of Assam Medical College \& Hospital, Dibrugarh. All the type 1 diabetic patients above 12 years of age attending the inpatient and outpatient department of this institution were included in the study after obtaining written consent.

\section{Case Definitions $(10)$}

Diagnosis of Type 1 Diabetes Mellitus was made in any patient presenting with hyperglycaemia (RBS $\geq 200 \mathrm{mg} / \mathrm{dL}$ or $11.1 \mathrm{mmol} / \mathrm{L}$ ) along with $\geq 1$ of clinical symptom of ketosis, rapid weight loss with $\mathrm{BMI}<25 \mathrm{~kg} / \mathrm{m}^{2}$, with onset of diabetes below 50 years of age or having personal or family history of autoimmune disorder.

\section{Methodology}

We enrolled 92 Type 1 diabetic patients in the study. After detailed history and clinical examination, relevant investigations were performed in the Multidisciplinary Research Laboratory of this institution which were filled in the predesigned proforma.

After 8 hours of fasting, blood specimen was collected from each participant and analysed for the following parameters. Plasma fasting glucose, postprandial blood glucose level was estimated by GOD/POD method in an autoanalyser. Estimation of Glycated Haemoglobin ( $\mathrm{HbA}_{1 \mathrm{c}}$ ) 
was done by High-performance liquid chromatography (HPLC assay) using the Biorad D 10 Machine.

Serum tri-iodothyronine, serum thyroxin and thyroid stimulating hormone were estimated in Mini-Vidas (BioMerieux). Other relevant investigations including Complete blood count, LFT, urine for microalbumin, Renal function test, Serum calcium were measured by standard methods. Estimation of TPO antibody was done by AccuBind ELISA micro wells, a sequential ELISA method. Anti-TPO-Ab level > $50 \mathrm{IU} / \mathrm{mL}$ was considered high.

\section{Statistical Evaluation}

The categorical variables were expressed as percentages whereas continuous variables were expressed as mean \pm standard deviation. Fisher's exact test and Chi-square test were done for Categorical variables and independent $\mathrm{t}$-test was used for Continuous variables for calculating $p$ value ( $p$ value $<0.05=$ significant). SPSS version 17 Software was used for Statistical analysis.

\section{RESULTS}

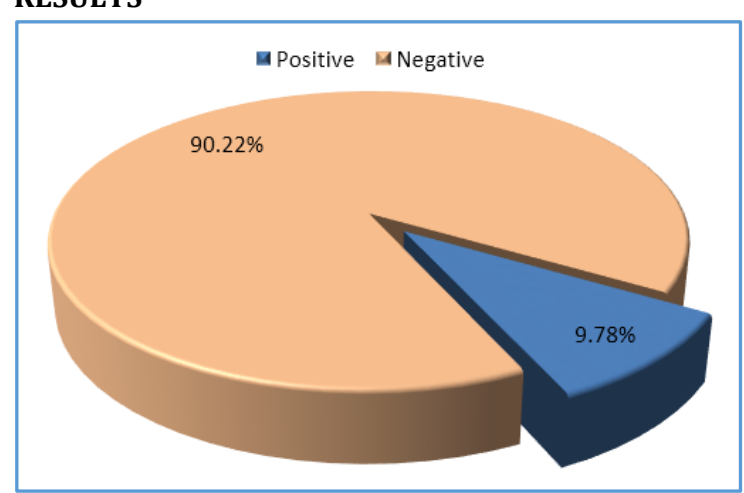

Figure 1. Prevalence of anti-TPO antibody

\begin{tabular}{|c|c|c|c|c|c|c|c|}
\hline & \multicolumn{2}{|c|}{$\begin{array}{c}\text { Anti-TPO Positive } \\
\text { T1DM }\end{array}$} & \multicolumn{2}{|c|}{$\begin{array}{c}\text { Anti-TPO } \\
\text { Negative T1DM } \\
\end{array}$} & \multicolumn{2}{|c|}{ Total } & \multirow[t]{2}{*}{ p value } \\
\hline & Mean & SD & Mean & SD & Mean & SD & \\
\hline Serum Anti-TPO antibody level & 122.18 & 18.40 & 10.78 & 6.14 & 21.68 & 34.21 & $<0.05$ \\
\hline Serum TSH $(\mu \mathrm{g} / \mathrm{L})$ & 16.05 & 22.52 & 2.29 & 1.62 & 3.64 & 7.99 & $<0.05$ \\
\hline $\mathrm{T} 3(\mathrm{ng} / \mathrm{dL})$ & 240.95 & 202.93 & 132.55 & 30.53 & 143.15 & 74.22 & $<0.05$ \\
\hline $\mathrm{T} 4(\mu \mathrm{g} / \mathrm{dL})$ & 29.19 & 43.46 & 8.09 & 16.96 & 10.15 & 21.56 & $<0.05$ \\
\hline Random & 603 & 87.78 & 571.84 & 113.01 & 574.89 & 110.78 & Not Significant \\
\hline Fasting & 308.11 & 127.62 & 262.39 & 107.82 & 266.86 & 109.97 & Not Significant \\
\hline Postprandial & 344 & 131.98 & 350.18 & 134.24 & 356.77 & 134.81 & Not Significant \\
\hline $\mathrm{HbA}_{1 \mathrm{C}}$ & 11.69 & 3.41 & 10.91 & 3.07 & 10.99 & 3.10 & Not Significant \\
\hline
\end{tabular}

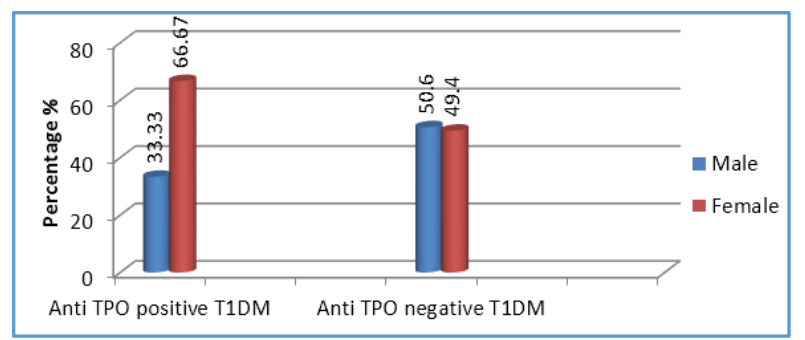

Figure 2. Sex Distribution of Anti-TPO Positive and Negative T1DM Patients

\begin{tabular}{|c|c|c|c|c|c|c|}
\hline \multirow{2}{*}{} & $\begin{array}{c}\text { Anti-TPO } \\
\text { positive } \\
\text { T1DM }\end{array}$ & $\begin{array}{c}\text { Anti-TPO } \\
\text { negative } \\
\text { T1DM }\end{array}$ & \multicolumn{2}{|c|}{ Total } \\
\cline { 2 - 7 } & Mean & SD & Mean & SD & Mean & SD \\
\hline Age (years) & 25 & 5.08 & 23.58 & 6.19 & 23.67 & 6.07 \\
\hline $\begin{array}{c}\text { Average duration } \\
\text { (months) }\end{array}$ & 33.44 & 40.81 & 33.82 & 49.03 & 34.69 & 40.09 \\
\hline $\begin{array}{c}\text { Table 2. Distribution of Anti-TPO Positive and Negative } \\
\text { T1DM Patients According to Average Age }\end{array}$ \\
\hline
\end{tabular}

\begin{tabular}{|c|c|c|c|c|c|c|}
\hline \multirow{2}{*}{ Caste } & $\begin{array}{c}\text { T1DM } \\
\text { with AITD }\end{array}$ & \multicolumn{2}{c|}{$\begin{array}{c}\text { T1DM } \\
\text { without AITD }\end{array}$} & \multicolumn{2}{|c|}{ Total } \\
\cline { 2 - 7 } & $\mathbf{n}$ & $\mathbf{\%}$ & $\mathbf{n}$ & $\mathbf{\%}$ & $\mathbf{N}$ & $\mathbf{\%}$ \\
\hline General & 3 & 33.33 & 20 & 24.1 & 23 & 25 \\
\hline OBC & 2 & 22.22 & 20 & 24.1 & 22 & 23.9 \\
\hline SC & 0 & 0 & 4 & 4.82 & 4 & 4.35 \\
\hline ST & 1 & 11.11 & 13 & 15.66 & 14 & 15.23 \\
\hline Tea tribes & 3 & 33.34 & 26 & 31.32 & 29 & 31.52 \\
\hline Others & 0 & 0 & 0 & 0 & 0 & 0 \\
\hline Total & 9 & $\mathbf{1 0 0}$ & $\mathbf{8 3}$ & $\mathbf{1 0 0}$ & $\mathbf{9 2}$ & $\mathbf{1 0 0}$ \\
\hline Table 3. Caste wise Distribution of Type 1 DM Patients \\
\multicolumn{7}{|c|}{ with and without AITD } \\
\hline
\end{tabular}

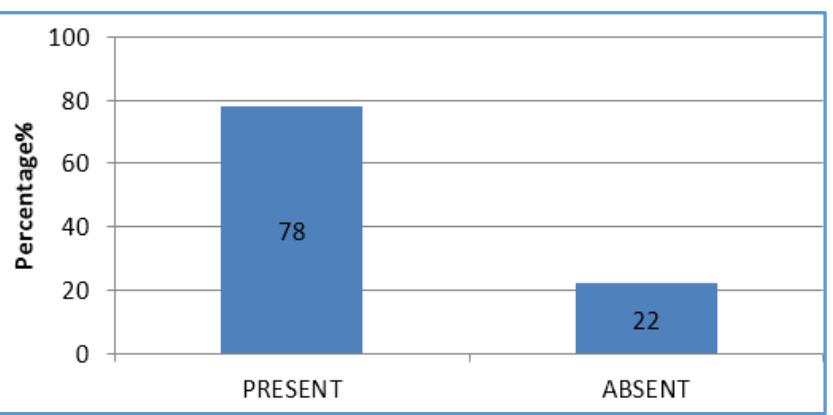

Figure 3. Symptoms of Thyroid Disorder in Anti-TPO Positive Patients

\begin{tabular}{|c|c|c|c|c|c|c|c|}
\hline \multirow{2}{*}{$\begin{array}{c}\text { AITD in } \\
\text { Relation to } \\
\text { BMI }\end{array}$} & \multicolumn{2}{|c|}{$\begin{array}{l}\text { T1DM } \\
\text { with } \\
\text { AITD } \\
\end{array}$} & \multicolumn{2}{|c|}{$\begin{array}{c}\text { T1DM } \\
\text { without } \\
\text { AITD }\end{array}$} & \multicolumn{2}{|c|}{ Total } & p value \\
\hline & $\begin{array}{l}\mathbf{n} \\
=9\end{array}$ & $\%$ & $\begin{array}{c}n \\
=83\end{array}$ & $\%$ & $\begin{aligned} & \mathbf{n} \\
= & 92\end{aligned}$ & $\%$ & \multirow{5}{*}{$\begin{array}{l}\quad<0.05 \\
\text { Significant }\end{array}$} \\
\hline $\begin{array}{c}\text { Underweight } \\
(<18.50)\end{array}$ & 4 & 44.44 & 40 & 48.2 & 44 & 47.83 & \\
\hline $\begin{array}{c}\text { Normal } \\
(18.5-24.99)\end{array}$ & 3 & 33.33 & 42 & 50.6 & 45 & 48.91 & \\
\hline $\begin{array}{c}\text { Overweight } \\
(>\text { or }=25)\end{array}$ & 2 & 22.22 & 1 & 1.2 & 3 & 3.26 & \\
\hline Total & 9 & 100 & 83 & 100 & 92 & 100 & \\
\hline
\end{tabular}

Table 4. Distribution of Patients with Type $1 \mathrm{DM}$ with and without AITD in Relation to BMI 


\begin{tabular}{|c|c|c|c|c|c|c|c|}
\hline \multirow{2}{*}{ Complication } & \multicolumn{2}{|c|}{ Anti-TPO Positive T1DM } & \multicolumn{2}{|c|}{ Anti-TP0 Negative T1DM } & \multicolumn{2}{|c|}{ Total } & \multirow[t]{2}{*}{ P value } \\
\hline & $\mathbf{n}=9$ & $\%$ & $\mathrm{n}=\mathbf{8 3}$ & \begin{tabular}{l|l}
$\%$ \\
\end{tabular} & $\mathrm{n}=92$ & $\%$ & \\
\hline Retinopathy & 1 & 11.11 & 9 & 10.84 & 10 & 10.87 & Not Significant \\
\hline Neuropathy & 4 & 44.44 & 16 & 19.28 & 20 & 21.74 & Not Significant \\
\hline Nephropathy & 5 & 55.55 & 14 & 16.87 & 19 & 20.65 & Not Significant \\
\hline Septicaemia & 5 & 55.55 & 24 & 28.92 & 29 & 31.52 & Not Significant \\
\hline DKA & 7 & 77.78 & 59 & 71.1 & 66 & 71.74 & Not Significant \\
\hline Anaemia $(\mathrm{Hb} \%<11 \mathrm{~g} / \mathrm{dL})$ & 6 & 66.67 & 21 & 25.3 & 27 & 29.35 & $<0.05$ Significant \\
\hline Hypoalbuminaemia $(<3.4 \mathrm{~g} / \mathrm{dL})$ & 7 & 77.78 & 24 & 28.92 & 21 & 22.83 & $<0.05$ Significant \\
\hline Elevated ALP $(>116 \mathrm{U} / \mathrm{L})$ & 3 & 33.33 & 19 & 22.89 & 22 & 23.91 & Not Significant \\
\hline Hypocalcaemia $(<8.5 \mathrm{mg} / \mathrm{dL})$ & 5 & 55.55 & 14 & 16.87 & 19 & 20.65 & $<0.05$ Significant \\
\hline $\begin{array}{c}\text { Low serum C-peptide level }(<0.5 \\
\text { ng/mL })\end{array}$ & 9 & 100 & 64 & 77.11 & 73 & 79.35 & \\
\hline
\end{tabular}

Table 5. Distribution of Anti-TPO Positive and Negative T1DM Patients with Complications

\section{DISCUSSION}

Prevalence of AITD in T1DM varies in different geographical regions due to different ethnicity. Some Indian studies found high prevalence of anti-TPO in T1DM as below (11):

\begin{tabular}{|c|c|c|c|}
\hline Study & Place & $\begin{array}{c}\text { No. of } \\
\text { T1DM } \\
\text { cases }\end{array}$ & $\begin{array}{c}\text { Prevalence of } \\
\text { anti-TPO } \\
\text { Positivity (\%) }\end{array}$ \\
\hline Honnamurthy et al & Kerala & 75 & $44(59 \%)$ \\
\hline Menon et al & New Delhi & 35 & $19(54.3 \%)$ \\
\hline Reddy et al & Tirupati & 22 & $9(41 \%)$ \\
\hline Goswami et al & New Delhi & 100 & $35(35 \%)$ \\
\hline Dayal et al & Chandigarh & 123 & $23(18.7 \%)$ \\
\hline
\end{tabular}

In our study, the prevalence was found to be $9.78 \%$. This is probably due to varied genetic makeup of the population in this part of the country. ${ }^{(12)}$ On the other hand, this prevalence rate coincides with the studies done in some other countries. (13) Female to male ratio of autoimmune thyroid disease is found to be $2: 1$ which also strengthens the hypothesis that autoimmune disorders are more common in female. This is because in females, estradiol seems to accelerate progression of autoimmune disease via enhancing the pathway of $\mathrm{T}$ helper type 2 (Th2) cells, while androgens had a protective effect. (14)

The average age of anti-TPO positive patients was $25 \pm$ 5.08 years. The prevalence of autoimmune thyroid disease varies depending on the age, sex and ethnic origin of the subjects and increases with duration of the disease. (15)

But contrary to this, we found that 4 out of 9 patients of AITD were diagnosed within one year of diagnosis of T1DM. So our study reveals that screening for autoimmune thyroid disorder is advisable in all T1DM patients at the time of diagnosis.

Four patients had clinical features of hypothyroidism with high TSH level and two had subclinical hypothyroidism. Three patients had features of hyperthyroidism with low TSH and high thyroid hormone level which had significant $\mathrm{p}$ value.

One important observation in our study is that $31.52 \%$ of T1DM patients belong to Tea tribe community and 3 had AITD. So genetic study is necessary to know the genetic predisposition.

Significant association was not found between the antiTPO positive and negative group regarding the complications of diabetes like DKA, retinopathy, neuropathy and nephropathy.
Though most of the T1DM patients presented with uncontrolled glycaemic status, no significant association was found between the anti-TPO positive and negative group.

There is a significant association of BMI in between the anti-TPO positive and negative group. Thyroid hormones are critically related to growth and developmental processes, so thyroid dysfunction poses detrimental effect on T1DM patients. Hypothyroidism usually associated with growth retardation while subclinical hypothyroidism increases dyslipidaemia and cardiovascular morbidity. Hyperthyroidism is most often associated with uncontrolled glycaemic status and increases the risk of DKA and neuromuscular dysfunction. So thyroid function test in T1DM should be done routinely.

In this study, we found significant association of anaemia, hypoalbuminaemia and hypocalcaemia between the anti-TPO positive and negative group. Association of other autoimmune disorders like autoimmune hepatitis, coeliac disease which lead to malabsorption may present with these pictures. But no study has mentioned regarding such findings. A large cohort study is necessary to evaluate these associations.

Regarding the elevated ALP and low serum C-peptide, no significant associations have been noticed between the antiTPO positive and negative group.

According to recent practical guidelines, ADA recommends for screening for AITD in all newly diagnosed T1DM by measuring anti-TPO and antithyroglobulin antibody along with measurement of serum TSH. If normal, depending upon the clinical symptom of thyroid dysfunction, thyromegaly, abnormal growth pattern, fluctuating blood glucose level, thyroid function and thyroid autoantibody should be monitored every 1 to 2 yearly.(16)

\section{CONCLUSION}

Co-occurrence of autoimmune thyroid disease in type 1 diabetes is not uncommon in this part of the country. High prevalence of T1DM and AITD in tea tribes in this region alarms us of the need for genetic study of this community. Early diagnosis of AITD in T1DM patients can improve growth and development. Routine haematological investigations should be done to rule out anaemia, hypoalbuminaemia, hypocalcaemia. Association of other autoimmune diseases like coeliac disease, autoimmune hepatitis should be checked as well in highly suspected cases. Our results indicate that all T1DM individuals should be screened with anti-TPO and TSH measurement at the time of diagnosis of diabetes. Anti-TPO-positive asymptomatic cases 
should undergo measurement of thyroid function at least once in a year.

\section{Limitations of the Study}

1. Small study population.

2. Ultrasonography of thyroid gland was not done.

3. Anti-thyroglobulin antibody measurement was not done.

\section{ACKNOWLEDGEMENT}

We express our gratitude to the institutional ethical committee for permitting us to conduct this study. We are thankful to all the staff of multidisciplinary laboratory of the institute.

\section{REFERENCES}

[1] Powers AC. Harrison's principles of internal Medicine. Chap 417. In: Dennis L. Casper MD. edr. Diabetes mellitus: diagnosis, classification and pathophysiology. 19th edn. New York: McGraw-Hill Education 2015.

[2] Crandall J, Shamoon H. Goldman-cecil medicine. In: Goldman L. edr. Diabetes mellitus. $25^{\text {th }}$ edn. Philadelphia: Elsevier Saunders 2016.

[3] Chan M. Director-General, WHO. Global report on diabetes, 2016

[4] You WP, Henneberg M. Type 1 diabetes prevalence increasing globally and regionally: the role of natural selection and life expectancy at birth. BMJ Open Diabetes Research and Care 2016;4(1):e000161.

[5] ADA: Standards of Medical Care in Diabetes. Diabetes Care 2016;39(Suppl 1)S1-S2.

[6] Barker JM, Yu J, Yu L, et al. Autoantibody "subspecificity" in type 1 diabetes: risk for organspecific autoimmunity clusters in distinct groups. Diabetes Care 2005;28(4):850-5.

[7] Lu MC, Chang SC, Huang KY, et al. Higher risk of thyroid disorders in young patients with Type 1 diabetes: a 12-year Nationwide, population-based, Retrospective Cohort Study. PLoS One 2016;11(3):e0152168.
[8] Subramanyam G, Pushparaj JL. Prevalence of anti-TPO antibody in type-1 diabetes and thyroid dysfunction in TPO antibody positive diabetics. Journal of Evolution of Medical and Dental Sciences 2012;1(5):668-76.

[9] Moayeri H, Rabbani A. Prevalence of autoantibodies to thyroid Peroxidase and autoimmune thyroid disease in Type I diabetes mellitus. Acta Medica Iranica 2004;42(4):267-71.

[10] NICE guideline. Type 1 diabetes in adults: diagnosis and management: nice.org.uk/guidance/ng17. 2015.

[11] Venkatanarasu A, Sachan A. Organ specific autoimmune disorders in type 1 diabetes mellitus. J Clin Sci Res 2017;6:103-12.

[12] Ramakrishna BS, Makharia GK, Chetri K, et al. Prevalence of adult celiac disease in india: regional variations and associations. Am J Gastroenterol 2016;111(1):115-23.

[13] Shiva S, Ilkhchooyi F, Rezamand A. Thyroid autoimmunity at the onset of type 1 diabetes mellitus in children. Open Journal of Immunology 2013;3:3740.

[14] Honnamurthy JB, Jagathlal PC, Subhakumari KN, et al. Prevalence of Anti thyroid peroxidase (Anti TPO) in type 1 diabetes mellitus. Thyroid Research and Practice 2011;8(2):13-6.

[15] Gonzalez GC, Capel I, Rodriguez-Espinosa J. Thyroid autoimmunity at onset of type 1 diabetes as a predictor of thyroid dysfunction. Diabetes Care 2007;30(6):e1611-2.

[16] Standards of medical care in diabetes-2015. Diabetes Care: The Journal of Clinical and Applied Research and Education. 2015;38(Suppl 1):S1-S93. 